\title{
PEMBERIAN TRICHOKOMPOS TANDAN KOSONG KELAPA SAWIT TERFORMULASI TERHADAP PERTUMBUHAN DAN HASIL TIGA VARIETAS BAWANG MERAH (Allium ascalonicum L.) DI LAHAN GAMBUT
}

\author{
Giving Trichokompos Oil Palm empty Bunches Formulated on Growth dan Yield Three Varietes \\ of Onion On Peatland (Allium ascalonicum L.)
}

\section{Dewi Marlina Susanti, Herman and Fifi Puspita}

\author{
Program Studi Ilmu Pertanian Pascasarjana Universitas Riau \\ Universitas Riau Kampus Bina Widya Km. 12,5 Simpang Baru Pekanbaru (28293) \\ Penulis Korespondensi: 08126806406. Email: dewimarlina07@gmail.com
}

\section{ABSTRACT}

This study aimed to get to know the effect of different doses formulated Trichokompos doses on the growth and production of onion varieties in peat area, as well as to get a dose of Trichokompos formulated and the best interaction on several onion varieties. Research using split plot design draft with 12 combination and each treatment was repeated 3 times, analyzed in the laboratory and analysis of variance. The main plot treatments consisted of: (V1): Varieties Bauji, (V2): Varieties Maja Cipanas, (V3): Varieties Bima Brebes. Treatment subplot, consists of 4 levels, namely: T1: (5 ton / ha), T2 (10 tons / ha), T3 (15 ton / ha) and T4 (20 ton / ha). The data obtained were statistically analyzed using analysis of variance (ANOVA) followed by HSD test at $5 \%$ level.

The results of the research showed that, the provision of oil palm empty bunches Trichokompos formulated doses of 10 ton / ha and a dose of 20 ton / ha on the varieties Bauji can increase the content of chlorophyll by $78.64 \%$ and $\mathrm{K}$ nutrient uptake value of $2.46 \mathrm{mg} /$ plant. Provision of Oil Palm Empty Fruit Bunch Trichokompos formulated doses of 10 ton / ha on Maja Cipanas varieties could increase plant height of $24.93 \mathrm{~cm}$ and a dose of 5 tonnes / ha can increase the diameter of the bulbs by $24.70 \%$ and the provision of oil palm empty bunches Trichokompos formulated doses of 5, 10, 15 and 20 ton / ha on Bima Brebes varieties can increase the number of tillers, the number of bulbs, tubers fresh weight, fresh weight of the plants, the rate of photosynthesis, transpiration rate, stomata conductivity, CO2 concentration, the value of $N$ uptake and nutrient uptake value P. Increasing doses of oil palm empty bunches Trichokompos formulated from 5 to 20 ton / ha on the varieties Bauji, Maja Cipanas and Bima Brebes not affect all parameters observed.

Keywords: Oil Palm Empty Fruit Bunch Trichokompos, Shallots, Bauji, Maja Cipanas, Bima Brebes, Peatland

\section{PENDAHULUAN}

Provinsi Riau memiliki potensi untuk pengembangan budidaya bawang merah di lahan gambut karena memiliki lahan gambut yang sangat luas. Luas gambut di Provinsi Riau mencapai 3.867.413 hektar merupakan separuh dari luas lahan pertanian yang ada (Balai Besar Penelitian dan Pengembangan Sumberdaya Pertanian, 2013).

Menurut Badan Penelitian dan Pengembangan Pertanian (2011), lahan yang ditanami tanaman perkebunan (896.245 ha) lebih luas dibandingkan lahan yang ditanami tanaman hortikultura (252.980 ha). Semakin lama luas lahan yang ditanami tanaman hortikultura semakin berkurang. Hal ini disebabkan karena banyaknya lahan yang ditanami tanaman hortikultura beralih fungsi ke tanaman perkebunan. Salah satu lahan yang masih berpotensi untuk digunakan sebagai lahan untuk hortikultura yaitu lahan gambut yang mempunyai kemampuan yang rendah dalam hal mendukung pertumbuhan tanaman.

Produksi bawang merah Provinsi Riau masih sangat sedikit. Menurut Badan Pusat Statistik Provinsi Riau (2013) produksi bawang merah di Riau hanya 12 ton / tahun dari luas lahan 10 ha 
sedangkan kebutuhan bawang merah untuk wilayah Riau mencapai 25 ribu ton / tahun.

Budidaya bawang merah dilahan gambut mempunyai kendala utama yaitu sifat kimia gambut, selain itu pengetahuan petani yang masih kurang tentang budidaya bawang merah di Riau dan tidak menguasai teknik budidaya bawang merah terutama di lahan gambut juga merupakan kendala dalam budidaya bawang merah. Sifat kimia gambut menurut Sasli (2011) antara lain: pH rendah, kapasitas tukar kation tinggi, kejenuhan basa rendah, kandungan unsur makro (K, Ca, Mg dan P) dan mikro (Cu, Zn, Mn dan B) rendah. Menurut Tan (1986) senyawa utama yang terdapat pada tanah gambut biasanya hemiselulosa, selulosa dan lignin. Biodegredasi lignin dapat menghasilkan asam-asam fenolat. Asam fenolat merupakan senyawa organik yang dapat bersifat racun bagi tanaman, oleh sebab itu perlu upaya untuk mengatasi kendala sifat kimia gambut yaitu pemberian Trichokompos tandan kosong kelapa sawit (TKKS) terformulasi. Penambahan Trichokompos sebagai bahan organik dapat menambah unsur hara yang dibutuhkan tanaman serta dapat memperbaiki kondisi lahan pertanian, sehingga diharapkan dapat meningkatkan produktivitas, serta dapat mengurangi biaya pemupukan kimia yang mahal serta tetap menjaga kualitas lingkungan.

Berdasarkan uraian di atas, maka pemberian Trichokompos terformulasi dalam rangka meningkatkan kesuburan tanah di lahan gambut untuk menunjang pertumbuhan dan hasil produksi umbi bawang merah sangatlah diperlukan, namun dosis Trichokompos terformulasi yang tepat bagi tanaman bawang merah belum diketahui khususnya lahan gambut di Riau. Oleh sebab itu, diharapkan dari penelitian ini diperoleh pertumbuhan, produksi dan kualitas umbi bawang merah yang lebih baik dan optimal di lahan gambut.

Penelitian ini bertujuan untuk mengetahui dosis Trichokompos TKKS terformulasi yang berbeda terhadap pertumbuhan dan hasil produksi pada beberapa varietas bawang merah di lahan gambut dan untuk mendapatkan dosis Trichokompos TKKS terformulasi, varietas bawang merah dan interaksi keduanya yang terbaik di lahan gambut.

\section{METODOLOGI PENELITIAN}

Penelitian ini dilaksanakan dari bulan Mei sampai Juli 2015 di lahan gambut kebun Percobaan Fakultas Pertanian Universitas Riau yang dan di Laboratorium di Fakultas Pertanian Universitas Riau.. Analisis tanah dilakukan di Laboratorium Ilmu Tanah Fakultas Pertanian Universitas Riau, dan analisis kompos TKKS di Laboratorium PT. Sarana Inti Pratama Pekanbaru. Bahan yang digunakan adalah benih bawang varietas Bauji, Maja Cipanas dan Bima Brebes, Trichokompos TKSS terformulasi, urea, $\mathrm{TSP}, \mathrm{KCl}$ dan dolomit. Alat yang digunakan adalah cangkul, meteran, clorofil meter, LI-COR LI-6400XT Portable Photosyntesis System, sekop, sabit, tali rapia, timbangan analitik, benang, gembor dan alat-alat tulis.

Penelitian dilakukan secara eksperimen dengan rancangan petak terpisah (split plot). Perlakuan petak utama terdiri dari: (V1): Varietas Bauji, (V2): Varietas Maja Cipanas, (V3): Varietas Bima Brebes. Anak petak dosis Trichokompos terformulasi dengan empat taraf yaitu: (T1) 5 ton/ha $\left(1,5 \mathrm{~kg} / \mathrm{m}^{2}\right.$, (T2): 10 ton/ha $\left(2,25 \mathrm{~kg} / \mathrm{m}^{2}, \mathrm{~T} 3: 15\right.$ ton/ha $\left(3 \mathrm{~kg} / \mathrm{m}^{2}\right)$ dan T4: 20 ton/ha $\left(3,75 \mathrm{~kg} / \mathrm{m}^{2}\right)$. Setiap kombinasi perlakuan diulang tiga kali. Parameter yang diamati tinggi tanaman,jumlah anakan perumpun, jumlah umbi per rumpun, Diameter umbi, bobot segar umbi per rumpun, bobot kering umbi per rumpun, jumlah khlorofil, fotosintesis, transpirasi, daya hantar stomata, konsentrasi $\mathrm{CO}_{2}$ dalam sel dan serapan N, P dan K.. Data hasil pengamatan dianalisis secara statistik dengan analisis ragam dan dilanjutkan dengan uji BNJ 5\%

\section{HASIL DAN PEMBAHASAN Sifat Kimia Tanah Penelitian}

Tabel 1 menunjukkan bahwa $\mathrm{pH}$ tanah gambut yang digunakan termasuk dalam kriteria masam. Kemasaman tanah gambut disebabkan oleh tingginya kandungan ion $\mathrm{H}^{+}$yang disumbangkan oleh asam organik penyusun gambut. Ion $\mathrm{H}^{+}$dalam senyawa organik mudah terdisosiasi. Sumber Ion $\mathrm{H}^{+}$berasal dari gugus- 
gugus reaktif seperti karboksilat $(-\mathrm{COOH})$ dan fenolat $\left(\mathrm{C}_{6} \mathrm{H}_{4} \mathrm{OH}\right)$ yang mendominasi komplek pertukaran dan bersifat sebagai asam lemah sehingga dapat terdisosiasi dan menghasilkan ion $\mathrm{H}^{+}$dalam jumlah banyak (Noor, 2001)

Kandungan C-organik, N-total dan nisbah $\mathrm{C} / \mathrm{N}$ tergolong sangat tinggi, sehingga $\mathrm{N}$ tidak tersedia bagi tanaman karena $\mathrm{N}$ masih sebagai bahan organik penyusun gambut. Nelvia et al., (2010) menyatakan jika kandungan $\mathrm{N}$ total, Corganik tinggi dan nisbah $\mathrm{C} / \mathrm{N}$ juga tinggi, berarti $\mathrm{N}$ merupakan penyusun bahan organik gambut dan tidak tersedia bagi tanaman.

Ketersediaan $\mathrm{P}$ dan $\mathrm{P}$ total tergolong sangat tinggi dan tinggi, hal ini disebabkan $\mathrm{P}$ total masih dalam bentuk $P$ organik dalam bahan organik penyusun gambut. Bahan organik juga dapat meningkatkan ketersedian $\mathrm{P}$ organik melalui beberapa reaksi sehingga $P$ tersedia menjadi sangat tinggi. Selain itu gambut yang digunakan adalah gambut dengan tingkat kematangan saprik sehingga bahan organik sudah terdekomposisi lanjut dan sudah termineralisasi, sehingga unsur $\mathrm{P}$ menjadi terlepas.

Kandungan Ca-dd, K-dd dan Mg-dd tergolong rendah sedang dan tinggi, Na-dd tergolong rendah dan $\mathrm{KB}$ sangat rendah. Hal ini disebabkan oleh disosiasi gugus karboksil yang melepaskan $\mathrm{H}^{+}$ke larutan dan koloid sehingga menjadi bermuatan negatif. Ratmini (2012) menyatakan bahwa tingginya KTK disebabkan oleh koloid tanah gambut yang bermuatan negatif, dan banyak mengandung asam-asam organik dengan gugus karboksil dan fenolik. Semakin tinggi gugus karboksil dan fenolik maka semakin tinggi pula KTK tanah gambut. Tanah gambut dengan ciri KTK sangat tinggi, tetapi persentase KB sangat rendah, akan menyulitkan penyerapan hara, terutama basa-basa yang diperlukan oleh tanaman. Hal ini juga dikemukakan oleh Nelvia et al., (2010) bahwa nilai KTK yang sangat tinggi tetapi KB rendah akan menghambat penyediaan hara terutama $\mathrm{K}$, $\mathrm{Ca}$ dan $\mathrm{Mg}$
Tabel 1. Sifat Kimia Tanah Penelitian

\begin{tabular}{lll}
\hline \multicolumn{1}{c}{$\begin{array}{c}\text { Sifat Kimia } \\
\text { Tanah }\end{array}$} & \multicolumn{1}{c}{ Nilai } & \multicolumn{1}{c}{ Kriteria } \\
\hline pH H2O & 4,95 & Masam \\
pH KCl & 4,74 & Masam \\
C Organik(\%) & 29,11 & Sangat Tinggi \\
N-Total (\%) & 0,67 & Tinggi \\
C/N & 43,31 & Sangat Tinggi \\
P Total (mg/100g) & 135,79 & Sangat Tinggi \\
K Total (mg/100g) & 48,2 & Sangat Tinggi \\
P Tersedia (ppm) & 27,49 & Tinggi \\
Kation & 2,95 & Rendah \\
basa(NH4OAc pH & & \\
7) & & \\
Ca-dd (me/100g) & 0,51 & sedang \\
K-dd (me/100g) & 2,75 & Tinggi \\
Mg-dd (me/100g) & 0,35 & Rendah \\
Na-dd (me/100g) & 89,80 & Sangat Tinggi \\
KTK (me/100g) & 7,27 & Sangat Rendah \\
KB (\%) & & \\
\hline
\end{tabular}

Kriteria mengacu pada pusat penelitian tanah (Laboratorium Tanah Bogor, 1983).

Tabel 2 menunjukkan bahwa TKKS bersifat agak alkalis dengan kandungan C-Organik, NTotal, $\mathrm{P}_{2} \mathrm{O}_{5}$ dan $\mathrm{K}_{2} \mathrm{O}$ sangat tinggi, $\mathrm{C} / \mathrm{N}$ sedang, $\mathrm{CaO}$ dan $\mathrm{MgO}$ tergolong sangat rendah dan rendah.

Tabel 2 Hasil Analisis Trichokompos TKKS Terformulasi.

\begin{tabular}{lll}
\hline Parameter & Nilai & Kriteria \\
\hline $\mathrm{pH} \mathrm{H}_{2} \mathrm{O}$ & 7,4 & Agak Alkalis \\
$\mathrm{C}$ organik $(\%)$ & 17,8 & Sangat Tinggi \\
$\mathrm{C} / \mathrm{N}$ & 10 & Sedang \\
$\mathrm{N}$ Total $(\%)$ & 1,77 & Sangat Tinggi \\
$\mathrm{P}_{2} \mathrm{O}_{5} \quad$ Total & 27,1 & Sangat Tinggi \\
$(\mathrm{g} / \mathrm{kg})$ & 25,2 & Sangat Tinggi \\
$\mathrm{K}_{2} \mathrm{O}(\mathrm{g} / \mathrm{kg})$ & 11,2 & Sangat Rendah \\
$\mathrm{CaO}(\mathrm{g} / \mathrm{kg})$ & 4,5 & Rendah \\
$\mathrm{MgO}(\mathrm{g} / \mathrm{kg})$ & & \\
\hline
\end{tabular}

Kriteria mengaju pada $p$ usat penelitian tanah (Laboratorium Tanah Bogor, 1983).

Tabel 3 menunjukkan hasil analisis tanah setelah perlakuan dapat nilai $\mathrm{pH}$ tanah dari kriteria masam menjadi agak masam. Hal ini di duga karena Trichokompos dapat meningkatkan kemampuan mengabsorsi kation, termasuk $\mathrm{H}^{+}$ sehingga kemasaman tanah berkurang dan $\mathrm{pH}$ tanah menjadi meningkat. 
Nilai $\mathrm{N}$ total untuk semua perlakuan meningkat kecuali nilai $\mathrm{N}$ total pada perlakuan Trichokompos dosis 15 ton/ha. Hal ini diduga karena dosis pupuk Trichokompos dan pupuk nitrogen yang diaplikasikan lebih sedikit bila dibandingkan dengan perlakuan lainnya, sehingga nilai serapan hara $\mathrm{N}$ lebih rendah bila dibandingkan dengan kombinasi perlakuan lainnya.

\section{Tinggi Tanaman dan Jumlah Anakan}

Tabel 4 menunjukkan bahwa peningkatan dosis Trichokompos TKKS terformulasi 5 sampai 15 ton/ha pada varietas Bauji dapat meningkatkan tinggi tanaman. Namun pada dosis Trichokompos TKKS terformulasi 5 sampai 10 ton/ha terlihat peningkatan tinggi tanaman pada varietas Maja Cipanas, hal ini diduga pada dosis 10 ton/ha sudah terpenuhi ketersediaan hara seperti unsur $\mathrm{N}$ untuk pertumbuhan tinggi Maja Cipanas. Peningkatan dosis Trichokompos TKKS terformulasi 5 sampai 20 ton/ha pada Varietas Bima Brebes terlihat tinggi tanaman cenderung menurun, hal ini berkaitan dengan ketersediaan $\mathrm{N}$ untuk pertumbuhan vegetatif tanaman. Hasil analisis tanah yang digunakan mengandung $\mathrm{N}$ total yang tinggi dan Tandan Kosong Kelapa Sawit terformulasi juga mengandung $\mathrm{N}$ yang tinggi.

Pada awal pertumbuhan, bawang membutuhkan $\mathrm{N}$ dalam jumlah yang banyak untuk digunakan ke pertumbuhan vegetatif awal.

\section{Tabel 4.}

Tinggi tanaman dan jumlah anakan bawang merah pada beberapa varietas yang diaplikasi

Trichokompos TKKS terformulasi

\begin{tabular}{cccc}
\hline $\begin{array}{c}\text { Petak } \\
\text { Utama } \\
\text { Varietas }\end{array}$ & $\begin{array}{c}\text { Anak Petak } \\
\text { Trichokompos } \\
\text { TKKS } \\
\text { terformulasi } \\
\text { (ton/ha) }\end{array}$ & $\begin{array}{c}\text { Tinggi } \\
\text { tanaman } \\
\text { (cm) }\end{array}$ & $\begin{array}{c}\text { Jumlah } \\
\text { anakan } \\
\text { (batang) }\end{array}$ \\
\hline \multirow{2}{*}{ Bauji } & 5 & $18,27 \mathrm{f}$ & $4,20 \mathrm{a}$ \\
& 10 & $19,80 \mathrm{de}$ & $4,20 \mathrm{a}$ \\
& 15 & $20,07 \mathrm{~d}$ & $3,60 \mathrm{a}$ \\
Maja & 20 & $20,07 \mathrm{~d}$ & $4,60 \mathrm{a}$ \\
Cipanas & 5 & $23,13 \mathrm{~b}$ & $3,87 \mathrm{a}$ \\
& 10 & $24,93 \mathrm{a}$ & $3,33 \mathrm{a}$ \\
& 15 & $22,20 \mathrm{bc}$ & $3,67 \mathrm{a}$ \\
& 20 & $23,27 \mathrm{~b}$ & $3,67 \mathrm{a}$ \\
\hline
\end{tabular}

\begin{tabular}{cccc}
\hline $\begin{array}{c}\text { Petak } \\
\text { Utama } \\
\text { Varietas }\end{array}$ & $\begin{array}{c}\text { Anak Petak } \\
\text { Trichokompos } \\
\text { TKKS } \\
\text { terformulasi } \\
\text { (ton/ha) }\end{array}$ & $\begin{array}{c}\text { Tinggi } \\
\text { tanaman } \\
(\mathbf{c m})\end{array}$ & $\begin{array}{c}\text { Jumlah } \\
\text { anakan } \\
\text { (batang) }\end{array}$ \\
\hline Bima & 5 & $21,40 \mathrm{~cd}$ & $5,60 \mathrm{a}$ \\
Brebes & 10 & $20,00 \mathrm{~d}$ & $5,00 \mathrm{a}$ \\
& 15 & $18,47 \mathrm{ef}$ & $5,20 \mathrm{a}$ \\
\hline
\end{tabular}

Ket: Angka pada setiap petak utama dan anak petak yang diikuti oleh huruf kecil yang sama, berbeda tidak nyata menurut uji BNJ 5\%

Riwandi (2000) menyatakan bahwa unsur N berperan dalam merangsang pertumbuhan vegetatif yaitu menambah tinggi tanaman. Lingga (2003) menyatakan bahwa peranan $\mathrm{N}$ penting dalam mendorong pertumbuhan vegetatif tanaman.

Pemberian dosis pupuk Trichokompos TKKS terformulasi yang tepat mampu memperbaiki sifat fisik tanah terutama terbentuknya struktur tanah baru, sifat fisik, kimia dan biologi tanah, Rahayu (2012) menyatakan bahwa penggunaan pupuk organik yang berimbang dapat meningkatkan kesuburan tanah melalui perbaikan sifat fisik memperbaiki struktur tanah, sifat kimia dapat meningkatkan ketersediaan unsur hara dalam tanah dan sifat biologi tanah meningkatkan aktivitas mikroorganisme dalam tanah mampu merombak bahan organik tanah menghasilkan ketersediaan unsur hara bagi tanaman serta mampu memperbaiki tata udara dan sirkulasi udara dalam tanah menjadi meningkat.

Maja Cipanas secara umum memiliki daya tumbuh yang tinggi dibandingkan varietas lain, hal Ini disebabkan karena faktor genetik dari pada verietas itu sendiri dan lingkungan tumbuh yang sesuai. Menurut Gardner et al.,(1985) bahwa pertumbuhan tanaman sangat dipengaruhi oleh faktor luar dan dalam. Faktor dalam salah satunya adalah sifat genetik dari varietas tersebut. Hal ini disebabkan masing masing varietas membawa sifat karakter genetik masing-masing terhadap pertumbuhan dan perkembangan bawang merah. Hal ini sesuai dengan literatur Sitompul dan Guritno (1995) yang menyatakan bahwa perbedaan susunan genetik merupakan salah satu faktor penyebab keragaman tanaman. Program 
genetik yang akan diekspresikan pada berbagai sifat tanaman yang mencakup bentuk dan fungsi tanaman yang menghasilkan keragaman pertumbuhan tanaman.

Sedangkan faktor luar adalah iklim, suhu, kelembaban, curah hujan, ketersediaan hara dan intensitas sinar matahari. Hasil penelitian Susanti (2015) menyatakan bahwa pemberian kompos pada varietas Maja Cipanas memberikan tinggi tanaman bawang tertinggi dengan rata - rata $33.35 \mathrm{~cm}$ dibandingkan varietas Batu Ijo dan Katumi.

Dari hasil penelitian jumlah anakan tidak sesuai dengan deskripsi (Lampiran 1) jumlah anakan masing-masing varietas. Hal ini disebabkan oleh perbedaan genetik dan pengaruh lingkungan tumbuh setiap varietas yang diadaptasikan. Hal ini disebabkan masing masing varietas membawa sifat karakter genetik masingmasing terhadap pertumbuhan dan perkembangan bawang merah.

Tidak terjadinya interaksi diduga ketersediaan unsur hara $\mathrm{N}$ sudah cukup tinggi di dalam tanah (Tabel 1) sehingga penambahan hara $\mathrm{N}$ dari Trichokompos TKKS terformulasi, sudah tidak direspon lagi oleh tanaman. $\mathrm{N}$ total sebelum diberi Trichokompos TKKS sebesar 0,67 (tinggi) sedangkan setelah di beri Trichokompos TKKS menjadi 0,75 (sangat tinggi).

\section{Jumlah Umbi dan Diameter Umbi}

\section{Tabel 5.}

Jumlah umbi dan diameter umbi bawang merah pada beberapa varietas yang diaplikasi

Trichokompos TKKS terformulasi

\begin{tabular}{cccc}
\hline $\begin{array}{c}\text { Petak } \\
\text { Utama } \\
\text { Varietas }\end{array}$ & $\begin{array}{c}\text { Anak Petak } \\
\text { Trichokompos } \\
\text { TKKS } \\
\text { terformulasi } \\
\text { (ton/ha) }\end{array}$ & $\begin{array}{c}\text { Jumlah } \\
\text { umbi }\end{array}$ & $\begin{array}{c}\text { Diameter } \\
\text { umbi } \\
(\mathbf{m m})\end{array}$ \\
\hline Bauji & 5 & $3,60 \mathrm{a}$ & $12,84 \mathrm{df}$ \\
& 10 & $4,44 \mathrm{a}$ & $12,00 \mathrm{fg}$ \\
& 15 & $5,13 \mathrm{a}$ & $14,18 \mathrm{be}$ \\
Maja & 20 & $4,72 \mathrm{a}$ & $12,44 \mathrm{eg}$ \\
\hline Cipanas & 5 & $2,78 \mathrm{a}$ & $16,81 \mathrm{a}$ \\
& 10 & $3,40 \mathrm{a}$ & $15,10 \mathrm{bc}$ \\
& 15 & $3,60 \mathrm{a}$ & $13,48 \mathrm{cf}$ \\
Bima & 20 & $3,27 \mathrm{a}$ & $15,88 \mathrm{ab}$ \\
Brebes & 5 & $8,50 \mathrm{a}$ & $10,90 \mathrm{~g}$ \\
\hline
\end{tabular}

\begin{tabular}{cccc}
\hline $\begin{array}{c}\text { Petak } \\
\text { Utama } \\
\text { Varietas }\end{array}$ & $\begin{array}{c}\text { Anak Petak } \\
\text { Trichokompos } \\
\text { TKKS } \\
\text { terformulasi } \\
\text { (ton/ha) }\end{array}$ & $\begin{array}{c}\text { Jumlah } \\
\text { umbi }\end{array}$ & $\begin{array}{c}\text { Diameter } \\
\text { umbi } \\
(\mathbf{m m})\end{array}$ \\
\hline & 15 & $7,67 \mathrm{a}$ & $11,79 \mathrm{fg}$ \\
& 20 & $6,20 \mathrm{a}$ & $12,87 \mathrm{df}$ \\
\hline
\end{tabular}

Ket: Angka pada setiap petak utam dan anak petak yang diikuti oleh huruf kecil yang sama, berbeda tidak nyata menurut uji BNJ 5\%.

Tabel 5 menunjukkan bahwa pemberian Trichokompos TKKS terformulasi 5 hingga 20 ton/ha berbeda tidak nyata pada varietas Bauji, Maja Cipanas dan Bima Brebes. Hal ini disebabkan jumlah umbi dipengaruhi oleh jumlah anakan. Nilai korelasi antara jumlah umbi dengan jumlah anakan sebesar $r=0,779$ yang berarti mempunyai hubungan korelasi yang kuat (Lampiran 9), sehingga peningkatan jumlah anakan mempengaruhi meningkatnya jumlah umbi. Hasil penelitian Arman (2016) menunjukkan bahwa peningkatan jumlah umbi juga dipengaruhi oleh meningkatnya jumlah anakan karena adanya korelasi yang positif.

Jumlah umbi pada varietas Bima Brebes menunjukkan lebih tinggi dibandingkan varietas Bauji dan Maja Cipanas. Hal ini disebabkan varietas Bima Brebes mampu beradaptasi pada iklim yang extrim sehingga dapat tumbuh dan berkembang dengan baik. Nazaruddin (1999) menyatakan bahwa Bima Brebes merupakan varietas bawang merah yang unggul dan bermutu baik sehingga dapat berkembang dengan baik dan dapat beradaptasi pada iklim yang extrim. Menurut Jimenes (2001) karakter ini disebabkan varietas tersebut tahan terhadap suhu tinggi dan memiliki tinggi tanam lebih baik, jumlah daun lebih banyak, dapat berbunga lebih cepat, jumlah umbi lebih banyak, bentuk dan diameter umbi lebih besar, memiliki berat yang stabil dan produksi yang lebih tinggi dari pada varietas lainnya.

Diameter varietas Maja Cipanas pada penelitian ini menunjukkan diameter yang terbesar. Hal ini disebabkan karena proses ketersediaan hara yang terus berjalan dari Trichokompos Tandan Kosong Kelapa Sawit yang diberikan, sehingga hara yang tersedia 
menjadi cukup dan seimbang. Peningkatan ketersediaan hara akan meningkatkan serapan hara oleh tanaman, sehingga fotosintesis berlangsung sempurna dan akan memacu proses fisiologis dan metabolisme tanaman, sehingga akan menghasilkan fotoasimilat berupa umbi. Diameter umbi sangat di pengaruhi oleh kemampuan tanaman untuk mentranslokasikan hasil fotosintat dari daun ke umbi. Lakitan (2008) menambahkan bahwa tanaman dapat menyerap unsur hara dengan baik. apabila unsur hara yang diberikan cukup, sehingga tanaman dapat tumbuh dan berproduksi dengan baik.

Kandungan unsur hara sangat dibutuhkan oleh tanaman bawang merah untuk dapat tumbuh optimal dan berproduksi tinggi, sebagai mana Rahayu dan Berlian (2004) menyatakan bahwa bawang merah membutuhkan unsur hara makro dan unsur hara mikro yang cukup agar tanaman mampu tumbuh optimal dan berproduksi tinggi, semakin besar diameter umbi yang dihasilkan maka semakin banyak unsur hara yang dimanfaatkan untuk perkembangan umbi.

Ketersediaan unsur $\mathrm{P}$ dan $\mathrm{K}$ yang cukup tinggi dari Trichokompos Tandan Kosong Kelapa Sawit yang diberikan mampu meningkatkan diameter bawang merah, karena unsur ini penting dalam pembentukan umbi bawang merah. Unsur $\mathrm{P}$ berfungsi untuk pertumbuhan ATP termasuk pembentukan umbi, sementara $\mathrm{K}$ memacu translokasi hasil fotosintesis dari daun ke bagian` lain tanaman dan berperan untuk pembentukan karbohidrat, sehingga meningkatkan diameter umbi bawang merah. Unsur P juga dimanfaatkan tanaman untuk proses metabolisme sel, sehingga proses fotosintesis berlangsung. Fotosintat yang dihasilkan dari proses fotosintesis dapat disimpan sebagai cadangan makanan dalam biji. Karbohidrat yang dihasilkan dari proses fotosintesis diangkut ke organ jaringan lain agar dimanfaatkan oleh organ jaringan tersebut untuk pertumbuhan atau ditimbun sebagai bahan cadangan seperti buah dan biji (Lakitan, 2000). Novizan (2002) menyatakan kekurangan unsur $P$ dan $\mathrm{K}$ dapat menyebabkan kematangan buah terlambat dan ukuran buah menjadi kecil.

Diameter umbi menurun akibat dipengaruhi oleh adanya korelasi antara dimeter umbi dengan jumlah umbi. Peningkatan jumlah umbi dapat mempengaruhi menurunnya diameter umbi. Akibat banyaknya jumlah umbi yang ditranslokasikan fotosintat, menyebabkan diameter umbi menjadi rendah. Sihombing (1997) menyatakan semakin banyak jumlah umbi per rumpun akan menyebabkan diameter umbi yang semakin kecil. Hasil penelitian Setiyowati et al., (2010) menyatakan bahwa ukuran umbi kecil merupakan indikasi kandungan senyawa organik didalam umbi sedikit, sehingga komponen berat kering yang diperoleh juga relatif sedikit.

Bobot Segar Umbi dan Bibit Tanaman

Tabel 5 menunjukkan bahwa pemberian Trichokompos Tandan Kosong Kelapa Sawit terformulasi 10 ton/ha pada varietas Maja Cipanas menghasilkan bobot segar umbi per rumpun paling tinggi yaitu $11,59 \mathrm{~g}$ dan meningkat 30,66 \% dibandingkan pemberian Trichokompos Tandan Kosong Kelapa Sawit terformulasi pada varietas lainnya. Hal ini dibuktikan pada tabel korelasi (Lampiran 9) yang memperlihatkan bahwa nilai bobot segar umbi berkorelasi positif dengan tinggi tanaman, daya hantar stomata dan laju transpirasi. Peningkatan tinggi tanaman diduga dapat meningkatkan luas permukaan daun, sehingga fotosintesis juga meningkat. Fotosintesis yang meningkat dapat meningkatkan fotosintat (hasil fotosintesis) yang dapat ditranslokasikan ke umbi tanaman.

Menurut Gardner et al., (1991) daun merupakan organ utama fotosintesis pada tumbuhan tingkat tinggi. Kebanyakan daun tanaman budidaya mempunyai permukaan luar yang luas dan datar yang memungkinnya menangkap cahaya semaksimal mungkin persatuan volume dan meminimalkan jarak yang harus ditempuh oleh $\mathrm{CO}_{2}$ dari permukaan daun ke kloroplas sehingga hasil fotosintesis lebih banyak diarahkan ke umbi. Munawar (2011) menyatakan fosfor merupakan esensial dalam proses fotosintesis dan metabolisme karbohidrat sebagai fungsi regulator pembagian hasil fotosintesis antara sumber dan organ reproduksi.

Trichokompos TKKS terformulasi adalah salah satu pupuk organik yang memiliki kemampuan dalam memperbaiki sifat fisik tanah 
dan memperbaiki air tanah. Perbaikan sifat fisik tanah tersebut berdampak positif terhadap pertumbuhan akar dan penyerapan unsur hara (Dinas Tanaman Pangan Provinsi Riau, 2006).

Tabel 5 menunjukkan pemberian Trichokompos TKKS terformulasi pada varietas Bima Brebes dosis 5 ton/ha berbeda tidak nyata pada dosis 10, 20 dan 25 ton/ha. Tabel 7 menunjukkan bahwa bobot kering tanaman tertinggi terdapat pada interaksi Trichokompos TKKS terformulasi dosis 15 ton/ha pada varietas Bima Brebes. Bobot kering tanaman dapat dipengaruhi oleh serapan N, P dan K. Nilai korelasi bobot kering tanaman dengan serapan $\mathrm{N}$, $\mathrm{P}$ dan $\mathrm{K}$ masing-masing adalah $\mathrm{r}=0,969,0,957$ dan 0,711 (Lampiran 9). Peningkatan serapan N, $\mathrm{P}$ dan $\mathrm{K}$ dapat meningkatkan bobot kering tanaman. Nitrogen dibutuhkan tanaman pada masa pertumbuhan vegetatif. Menurut Anisyah et al., (2014) pembentukan umbi bawang merah berasal dari pembesaran lapisan-lapisan daun yang kemudian berkembang menjadi umbi bawang merah. Fosfor (P) berperan dalam pembelahan dan pertumbuhan sel. Kalium yang tinggi menyebabkan ion $\mathrm{K}^{+}$yang mengikat air dalam tubuh tanaman akan mempercepat proses fotosintesis.

\section{Kandungan Khlorofil dan Laju Fotosintesa}

Pada dosis 10 ton/ha Trichokompos TKKS terformulasi cenderung meningkatkan kandungan khlorofil pada varietas Bauji sebesar $78,64 \%$ dan merupakan kandungan khlorofil tertinggi dibandingkan varietas lain. Hal ini disebabkan kandungan klorofil dipengaruhi oleh jumlah protein yang terdapat pada daun, dimana daun banyak mengandung protein. Menurut Dwijoseputro (1980) faktor-faktor yang berpengaruh terhadap pembentukan klorofil adalah faktor pembawaan cahaya, oksigen, karbohidrat, hara, nitrogen, magnesium, besi serta air dan suhu. Nitrogen, magnesium dan besi sudah menjadi keharusan dalam pembentukan klorofil. Kekurangan akan unsur-unsur tersebut akan menyebabkan klorosis pada tumbuhan. Menurut Prasetya et al., (2009) nitrogen merupakan salah satu unsur penyusun klorofil.
Menurut Salisbury dan Ross (1995) kloroflas mengandung sekitar separuh protein total dalam daun dan sekitar seperempat sampai setengah dari protein daun adalah rubisko. Salah satu yang mempengaruhi penyusunan kandungan klorofil adalah hara $\mathrm{Mg}$, sementara kandungan $\mathrm{Mg}$ pada trichokompos TKKS terformulasi sangat rendah yaitu $0,55 \%$ (Lampiran 2) sehingga kandungan klorofil tidak berbeda.

Pemberian Trichokompos

TKKS terformulasi dengan dosis 5, 10, 15 dan 20 ton/ha berbeda tidak nyata pada varietas Bauji, Bima Brebes dan Maja Cipanas terhadap laju fotosintesis. Pemberian Trichokompos TKKS terformulasi dosis 20 ton/ha pada varietas Bima Brebes dapat meningkatkan laju fotosintesis sebesar 19,58 \%. Laju fotosintesis juga dipengaruhi oleh konsentrasi $\mathrm{CO}_{2}$ di dalam sel. Konsentrasi $\mathrm{CO}_{2} \quad$ (Tabel 12) menunjukkan berbeda tidak nyata sehingga menyebabkan laju fotosintesa berbeda tidak nyata. Lakitan (2011) menyatakan bahwa salah satu faktor yang mempengaruhi laju fotosintesis adalah ketersediaan $\mathrm{CO}_{2}$.

Menurut Hasil Penelitian Arman (2016) menunjukkan bahwa peningkatan konsentrasi $\mathrm{CO}_{2}$ di dalam sel dapat meningkatkan laju fotosintesis. Menurut Dwijoseputra (1989) dengan adanya fotosintesis ini, maka kadar $\mathrm{CO}_{2}$ dalam sel-sel tersebut menurun. Ini karena sebahagian dari $\mathrm{CO}_{2}$ mengalami reduksi menjadi $\mathrm{CH}_{2} \mathrm{O}$, karena peristiwa reduksi ini maka berkuranglah ion-ion $\mathrm{H}$, sehingga $\mathrm{pH}$ ini sangat baik bagi kegiatan enzim posporitase guna mengubah amilum dalam sel penutup menjadi glukosa -1 pospat. Naiknya isi sel penutup menyebabkan masuknya air dari sel tetangga, sehingga menaikkan turgor dan mengembanglah dinding sel tetangga yang tipis tersebut.

\section{Laju Transpirasi dan Daya Hantar Stomata}

Pada dosis 15 ton/ha Trichokompos TKKS terformulasi meningkatkan laju transpirasi dalam sel pada varietas Bima Brebes sebesar 47,44\%. Menurut Arman (2016) peningkatan laju transpirasi pada pemberian Trichokompos TKKS terformulasi dipengaruhi peningkatan daya 
hantar stomata, dimana terdapat korelasi yang kuat antara laju transpirasi dengan Daya hantar stomata adalah $\mathrm{r}=0,856$ (Lampiran 9). Daya hantar stomata meningkat disebabkan stomata terbuka. Stomata terbuka akibat meningkatnya turgiditas sel pada stomata sehingga dapat meningkatkan laju transpirasi. Koning (1994) menunjukkan bahwa laju transpirasi akan meningkat sejalan dengan tingkat membukanya stomata (stomate aperture), dan tingkat evapotranspirasi interseluler jaringan mesofil daun sangat ditentukan oleh beda potensial air jaringan xilem, mesofil dan atmosfer. Aktivitas membuka menutupnya stomata merupakan mekanisme kontrol terhadap laju kehilangan air melalui transpirasi. Laju transpirasi akan meningkat bila stomata membuka.

Pemberian Trichokompos TKKS terformulasi dengan dosis 5,10, 15 dan 20 ton/ha berbeda tidak nyata pada varietas Bauji, Bima Brebes dan Maja Cipanas terhadap daya hantar stomata. Pada dosis 5 ton/ha Trichokompos TKKS terformulasi meningkatkan daya hantar stomata pada varietas Bima Brebes sebesar 9,61 $\%$. Hal ini disebabkan rendahnya atau kurangnya kandungan klorofil dan laju fotosintesis. Menurut Salisbury dan Ross (1995), stomata membuka karena meningkatnya pencahayaan dan cahaya menaikkan suhu daun sehingga air menguap lebih cepat. Naiknya suhu membuat udara mampu membawa lebih banyak kelembaban, maka transpirasi meningkat. Laju transpirasi akan meningkat bila stomata membuka.

Daya hantar stomata dapat dipengaruhi oleh kandungan klorofil dan laju fotosintesis. Peningkatan kandungan klorofil dan laju fotosintesis dapat meningkatkan Daya hantar stomata. Klorofil merupakan organ tanaman yang berperan menyerap cahaya. Peningkatan penyerapan cahaya dapat meningkatkan suhu pada daun. Naiknya suhu dapat meningkatkan keluarnya $\mathrm{H}_{2} \mathrm{O}$ dari stomata sehingga Daya hantar stomata meningkat. Salisbury dan Ross (1995) menyatakan stomata membuka karena meningkatnya pencahayaan, dan cahaya menaikkan suhu daun sehingga air menguap lebih cepat. Naiknya suhu membuat udara mampu membawa lebih banyak kelembapan, maka transpirasi meningkat.

\section{Konsentrasi $\mathrm{CO}_{2}$}

Pada dosis 10 ton/ha Trichokompos TKKS terformulasi dapat meningkatkan konsentrasi $\mathrm{CO}_{2}$ dalam sel pada varietas Bima Brebes sebesar $8.71 \%$ pada dosis 5 ton/ha. Menurut hasil penelitan Arman (2016), Konsentrasi $\mathrm{CO}_{2}$ dalam sel dipengaruhi oleh daya hantar stomata. Karbondioksida $\left(\mathrm{CO}_{2}\right)$ hasil fiksasi $\mathrm{CO}_{2}$ dari udara pada saat fotosintesis. Sewaktu tanaman memfiksasi $\mathrm{CO}_{2}$ dari udara, tanaman mengeluarkan $\mathrm{H}_{2} \mathrm{O}$ sehingga peningkatan daya hantar stomata dapat meningkatkan konsentrasi $\mathrm{CO}_{2}$ dalam sel. Molekul $\mathrm{H}_{2} \mathrm{O}$ yang berdifusi keluar dari stomata mempengaruhi masuknya molekul $\mathrm{CO}_{2}$ (Von dan Farquhar ,1981)

\section{Nilai serapan hara N, P dan K pada umbi} bawang merah

Tabel 9 menunjukkan bahwa pemberian Trichokompos TKKS terformulasi pada varietas varietas Bima Brebes mempunyai nilai serapan nitrogen tertinggi pada dosis 15 ton/ha. Hal ini diduga Trichokompos TKKS terformulasi dapat meningkatkan ketersediaan hara terutama $\mathrm{N}$ yang membuat pertumbuhan tanaman bawang merah yang ditanam dilahan gambut menjadi lebih baik.

Hasil penelitian Nursyamsi (2015) bahwa pemberian Trichokompos TKKS terformulasi 30 ton/ha meningkatkan nilai serapan hara $\mathrm{N}$ sebesar 1,6 kali dibandingkan dengan pemberian 15 ton/ha. Rasio C/N dari penelitian tersebut 19,3. lebih rendah dari analisa awal 26,5 sehingga pupuk ini lebih mudah terdekomposisi dan dapat meningkatkan ketersediaan hara terutama nitrogen yang membuat pertumbuhan tanaman bawang merah yang di tanam pada lahan gambut menjadi lebih baik. Hal ini disebabkan peningkatan dosis Trichokompos TKKS terformulasi dapat meningkatkan ketersediaan hara dalam tanah salah satunya adalah hara nitrogen sehingga dapat diserap oleh akar tanaman

Meningkatnya serapan $\mathrm{N}$ maka akan mendorong pertumbuhan dan produksi tanaman menjadi lebih baik. Masnanto (2006) menyatakan 
bahwa pemupukan nitrogen pada tanaman bawang merah dilahan sawah sampai dosis 200 $\mathrm{kg} / \mathrm{ha}$ dapat meningkatkan serapan hara N. Hasil penelitian Elizabeth (2013) pemberian kompos jerami dan pupuk NPK dapat meningkatkan tinggi tanaman padi berhubungan dengan meningkatnya ketersediaan nitrogen dalam tanah dan serapan nitrogen oleh tanaman.

Tabel 9 diketahui bahwa pada varietas Bima Brebes, serapan hara $\mathrm{P}$ tertinggi pada umbi bawang merah pada dosis 15 ton/ha. Hal ini disebabkan karena pemberian Trichokompos TKKS terformulasi dapat meningkatkan ketersediaan hara $\mathrm{P}$. Peningkatan serapan $\mathrm{P}$ tanaman sangat ditentukan oleh konsentrasi $\mathrm{P}$ dalam tanah serta kemampuan tanaman dalam menyerap unsur $\mathrm{P}$ dalam tanah. Dimana pemberian bahan organik berfungsi untuk memenuhi kebutuhan hara tanaman sehingga memungkinkan tanaman dapat tumbuh dan berkembang dengan baik. Hasil penelitian Wahyudi (2013), Peningkatan serapan P oleh tanaman bawang merah kultivar Palu ini berkaitan erat dengan adanya suplai unsur hara $P$ yang terkandung dalam ekstrak kompos limbah organik pasar yang dapat meningkatkan ketersediaan unsur $\mathrm{P}$ bagi tanaman.

Semakin besar dosis Trichokompos TKKS terformulasi yang diberikan, semakin rendah serapan $\mathrm{P}$ pada varietas maja cipanas. Hal ini disebabkan akibat tingginya konsentrasi hara dalam larutan tanah yang melebihi ambang batas toleransi tanaman dalam bermetabolisme. Apabila konsentrasi ion di dalam tanah terlalu tinggi sedangkan toleransi tanaman untuk penyerapan tersebut sudah tidak mencukupi lagi maka sel dalam jaringan tanaman (terutama akar) akan pecah. Ini menyebabkan sistem perakaran pada tanaman menjadi rusak. Bila sistem perakaran rusak, maka pertumbuhan akar tanaman dan pembentukan bulu akar juga terhambat sehingga translokasi hara ke organ tanaman lain seperti daun, buah dan biji ikut terhambat.

Pada varietas Bima Brebes, serapan $\mathrm{P}$ tertinggi terdapat pada perlakuan dengan dosis 15 ton/ha yaitu sebesar 2,45 \%. Menurut Sadjad (1993), perbedaan daya tumbuh antar varietas yang berbeda ditentukan oleh faktor genetiknya. Selain itu, potensi gen dari suatu tanaman akan lebih maksimal jika didukung oleh faktor lingkungan. Varietas Bima Brebes mampu beradaptasi dengan lingkungan jika dibandingkan dengan varietas Bauji dan Maja Cipanas.Adaptasi yang baik terhadap lingkungan akan berdampak pada produksi atau hasil tanaman itu sendiri.

Serapan $\mathrm{P}$ juga dapat dipengaruhi oleh serapan $\mathrm{N}$ dan serapan $\mathrm{K}$. Hal ini terlihat adanya korelasi antara Serapan $\mathrm{P}$ dengan serapan $\mathrm{N}$ dan serapan $\mathrm{K}$ masing-masing yaitu 0,948 dan 0,667 (Lampiran 9). Tanaman menyerap hara dalam keadaan seimbang. Peningkatan serapan $\mathrm{N}$ dan $\mathrm{K}$ dapat mempengaruhi serapan P. Menurut Arman (2016) kemampuan tanaman dalam menyerap P secara optimal diperoleh pada kondisi keseimbangan hara.

Tabel 9 pemberian Trichokompos TKKS terformulasi pada varietas Bauji dengan dosis 20 ton/ha merupakan kombinasi perlakuan yang memiliki nilai serapan hara kalium tertinggi dibandingkan pemberian Trichokompos TKKS terformulasi dengan dosis 5,10 dan 15 ton/ha. Pada varietas Maja cipanas, pemberian Trichokompos TKKS Terformulasi dosis 5 ton/ha memiliki serapan hara tertinggi sebesar 2,47 \%. Pada varietas Bima Brebes serapan K tertinggi terdapat pada pemberian Trichokompos TKKS Terformulasi dosis 15 ton/ha. Menurut penelitian Herlina (2015), bahwa pemberian Trichokompos TKKS terformulasi dosis 25 ton/ha meningkatkan nilai serapan hara $\mathrm{K}$ sebesar 2,8 kali (185\%) dibandingkan dengan pemberian 15 ton/ha. Hal ini disebabkan peningkatan dosis Trichokompos TKKS terformulasi tentu diikuti oleh peningkatan ketersediaan unsur hara, khususnya hara K sehingga dapat diserap oleh akar tanaman.

\section{KESIMPULAN}

Pemberian dosis Trichokompos TKKS terformulasi 20 ton/ha pada varietas Bima Brebes dapat meningkatkan bobot segar sebesar 10,44 $128,98 \%$ dibandingkan dosis Trichokompos TKKS terformulasi 5, 10 dan 15 ton/ha pada varietas Bauji dan Maja Cipanas. 


\section{DAFTAR PUSTAKA}

Anisyah. F., R. Sipayung dan C. Hanum. 2014. Pertumbuhan dan Produksi Bawang Merah dengan Pemberian Berbagai Pupuk Organik. Jurnal Online Agroteknologi ISSN No. 2337- 6597 Vol.2, No.2: 482- 496, Maret 2014. Tanggal Akses: 7 Agustus 2016.

Arman, Z. 2016. Respon, Fisiologi, Pertumbuhan, Produksi dan Serapan P Bawang Merah (Allium ascalonicum L.) Terhadap Pemberian Trichokompos Tandon Kosong Kelapa Sawit Terformulasi dan Pupuk P di Lahan Gambut. Universitas Riau. Pekanbaru.

Balai Besar Penelitian dan Pengembangan Sumberdaya Lahan Pertanian. 2011. Laporan tahunan 2011, Konsorsium penelitian dan pengembangan perubahan iklim pada sektor pertanian. BBPPSLP. Bogor

Badan Penelitian dan Pengembangan Sumberdaya Pertanian. 2013. Prosiding Seminar Nasional, Pengelolaan Lahan Gambut Berkelanjutan. Cimanggu, Bogor.

Balai Pengkajian Teknologi Jambi. 2009. Pemanfaatan Trichokompos pada Tanaman Sayuran. Buletin Agro Inovasi. BPTP Jambi

Badan Pusat Statistik. 2013. Produksi Produktivitas Bawang Merah. Riau dalam angka. Pekanbaru

Badan Pusat Statistik. 2015. Luas Panen, Produksi dan Produktivitas Bawang Merah, 2009-2014. www.bps.go.id. Akses tgl: 04 Februari 2015.

Dinas Pertanian. 2011.Bawang Merah. Dinas Pertanian D.I.Yogyakarta. http://distan.pemda-diy.go.id. Tanggal Akses tgl:8 Maret 2014.

Ditjen PPHP. 2006. Pedoman Pengolahan Limbah Industri Kelapa Sawit. Subdit Pengelolaan Lingkungan. Direktorat Pengolahan Hasil Pertanian.

Dwijoseputro, D. 1980. Pengantar Fisiologi Tumbuhan.Gramedia. Jakarta
Elisabeth, W.D., M. Santosadan N. Herlina. 2013Pengaruh Pemberian Berbagai Komposisi Bahan Organik pada Pertumbuhan danHasil Tanaman Bawang Merah (Allium ascalonicum L.) Jurnal Produksi Tanaman Vol.1(3).

Gardner et.al. 1985. Fisiologi Tanaman Budidaya. Susilo, $\mathrm{H}$ dan Subiyanto (Penerjemah). UI Press: Jakarta

Herlina., F. 2015. Pertumbuhan dan Produksi Bawang Merah (Allium ascalonicum L.) dengan Pemberian Trichokompos Tandan Kosong Kelapa Sawit Terformulasi dan Pupuk Kalium di Lahan Gambut. Universitas Riau, Pekanbaru.

Jimenes. 2001. Pengkajian paket teknik budidaya bawang merah di luar musim. Pros Semi Hasil Paket Penelitian/Pengkajian BPTP Karangploso, Vol. 12 7(6): 27-29.

Lakitan, B. 2011. Dasar-dasar Fisiologi Tumbuhan. PT. RajaGrafindo Persada. Jakarta.

Lingga P Dan Marsono, 2005. Petunjuk Penggunaan Pupuk. Penebar Swadaya, Jakarta. Hal 8 dan 3.

Masnanto, A. 2006. Pengaruh Jarak Tanam dan Dosis 1Jrea Terhctdap Pertumbuhan, Hasil dan Kualitas Umbi Bibit Bawang Merah (Allium cepa L). Tesis S2. Pascasariana UGM Yogyakarta.

Munawar, A. 2011. Kesuburan Tanah dan Nutrisi Tanaman. IPB press. Bogor.

Nazaruddin. 1999. Budidaya dan pengaturan panen sayuran dataran rendah. Penebar Swadaya.

Nelvia, Rosmini dan Sinaga. J. 2010. Pertumbuhan dan Produksi Jagung Manis (Zea Mays var Succhrata Sturt) pada Tanah Gambut yang Diaplikasi Amelioran Dregs dan Fospat Alam.

Noor, M. 2001. Pertanian Lahan Gambut. Potensi dan Kendala. Kanisius. Yogyakarta.

Novizan.2002. Petunjuk Pemupukan yang Efektif. Agro Media Pustaka, Jakarta.

Nursyamsi, D. 2006. Kebutuhan pupuk kalium tanah Ultisol untuk kedelai. Jurnal Tanah dan Lingkungan. 
Prasetya, B., S. Kurniawan dan Febrianingsih. 2009. Pengaruh Dosis dan FrekuensiPupuk Cair Terhadap Serapan danPertumbuhan Sawi (Brassica junsea L. ) Pada Entisol. Univ. Brawijaya. Malang

Rachim A. 1995. Penggunaan kation-kation polivalen dalam kaitannya dengan ketersediaan fosfat untuk meningkatkan produksi jagung pada tanah gambut. Disertasi Program Pasca Sarjana Institut Pertanian Bogor.

Rahayu, E., dan N. Berlian. 2004. Mengenal Varietas Ungul dan Cara Budidaya Kontinyu Bawang Merah. Penebar Swadaya, Jakarta.

Ratmini NPS. 2012. Karakteristik dan Pengelolaan Lahan Gambut Untuk Pengembangan Pertanian.Jurnal Lahan Suboptimal. Vol. 1, No. 2 Hal: 197-206.

Salisbury, F.B. dan C.W. Ross. 1995. Fisiologi Tumbuhan. Terjemahan D.R. Lukman dan Sumaryono. Penerbit ITB. Bandung.

Sadjad, S. 1993. Dari Benih Kepada Benih. Grasindo, Jakarta.

Sasli, I. 2011. Karakterisasi Gambut Dengan Berbagai Bahan Amelioran dan
Pengaruhnya Terhadap Sifat Fisik dan Kimia Guna Mendukung Produktivitas Lahan Gambut. Jurnal Agrovigor 4 (1): 42-50.

Sihombing, P dan R. M. Sinaga. 1983. Penyimpanan Umbi Bibit Kentang di Ruas Terang. Bulletin Penelitian Vol X No 3(2): 7-11.

Sitompul S M; Guritno B. 1995. Analisis Pertumbuhan Tanaman. UGM Press,

Yogyakarta.

Susanti, D.S., 2015. Pemberian Berbagai Jenis Kompos Pada Pertumbuhan dan Hasil Tanaman Bawang Merah (Allium ascalanicum. L) di Kabupaten Enrekang. Faperta Unmus.

Von, C. and Farquhar. 1981. Some relationship between biochemistry of photosynthesis and the gas exchange of leaves. Planta 153: $376-387$.

Wahyudi, I. 2013. Perubahan Tingkat Serapan Nitrogen, Fosfor dan Kalium Oleh Tanaman Bawang Merah Lokal Palu Akibat Pemberian Ekstrak Kompos Limbah Organik Pasar Pada Entisol Poboya. Tanggal Akses: 1 Maret 2016. 